\title{
Environment has a Stronger Effect than Host Plant Genotype in Shaping Spring Brassica napus Seed Microbiomes
}

\author{
Zayda P. Morales Moreira, ${ }^{1, \dagger}$ Bobbi L. Helgason, ${ }^{2}$ and James J. Germida ${ }^{2}$ \\ ${ }^{1}$ Department of Food and Bioproduct Sciences, University of Saskatchewan, Saskatoon, SK, S7N 5A8, Canada \\ ${ }^{2}$ Department of Soil Science, University of Saskatchewan, Saskatoon, SK, S7N 5A8, Canada
}

Accepted for publication 10 January 2021.

\section{ABSTRACT}

Seed are reproductive units that transfer genetic information to the next generation and harbor microbial communities that may interact with a host plant at all stages of its development. Here, we assessed the effect of the environment and plant genotype on the seed microbiome of eight spring Brassica napus lines harvested from four site years in Saskatchewan, Canada: one location each in 2016 and 2017 and two additional locations in 2017. Seed microbiomes were characterized using high-throughput amplicon sequencing of the bacterial $16 \mathrm{~S}$ ribosomal RNA and fungal internal transcribed spacer regions. Our results revealed that microbial communities were predominantly shaped by the environment, with location explaining $34 \%$ of bacterial and $43 \%$ of fungal total variance. Meanwhile, genotype had a smaller effect, accounting for only $9 \%$ of bacterial and $13 \%$ of fungal variance. The seed microbiome of $B$. napus predominantly contained members of
Enterobacteriales and Pseudomonadales bacterial orders as well as Pleosporales and Capnodiales fungal orders. Additionally, common taxa, including Enterobacteriales, Pseudomonadales, Micrococcales, Sphingomonadales, Pleosporales, Capnodiales, Tremellales, Filobasidiales, and Sporidiobolales, were detected across all site years. Our results demonstrate that the environment plays a dominant role in shaping spring $B$. napus seed microbiomes, with more subtle contributions related to host plant genotype. Information collected in this study may contribute to the development of novel and sustainable breeding and agricultural strategies that consider microorganisms carried by seed.

Keywords: agriculture, canola, crop, environment, host genotype, microbiome, seed microbiome
The plant microbiome contributes a significant level of genetic information that influences plant fitness (Sessitsch and Mitter 2015; Zilber-Rosenberg and Rosenberg 2008). Thus, microbial communities can be either beneficial or deleterious for plant growth, development, and function, thereby affecting productivity and yield of agricultural crops (Andreote and Pereira e Silva 2017; Tosi et al. 2020). Each plant compartment, including reproductive organs such as flowers (Arunkumar et al. 2019), fruit (Droby and Wisniewski 2018), and seed (Nelson 2018), provides resources and habitat for a huge number of microbes, which colonize external and internal

\section{${ }^{\dagger}$ Corresponding author: Z. P. Morales Moreira; z.morales@usask.ca}

Funding: This research was supported by the Discovery Grant Program of the Natural Sciences and Engineering Research Council of Canada, the Saskatchewan Canola Development Commission, and the Plant Phenotyping and Imaging Research Centre; funded by the Canada First Research Excellence Fund, managed by the Global Institute for Food Security.

*The $\boldsymbol{e}$-Xtra logo stands for "electronic extra" and indicates that supplementary tables and supplementary figures are published online.

The author(s) declare no conflict of interest.

(C) 2021 The American Phytopathological Society plant tissues. Seed not only represent the starting point for a broad variety of plant species but also store and carry microbes that will continue to interact with the plant throughout its life cycle (Gopal and Gupta 2016). Thus, a plant's first microbial inoculum comes from the seed.

Climate change, ecosystem degradation, and biodiversity loss significantly affect agriculture and food security; looking for sustainable strategies and practices is essential to ensure the global nutritional demand (Toju et al. 2018). Exploring plant microbiome functions is one approach that can mitigate adverse effects caused by biotic and abiotic stresses affecting plant fitness (OrozcoMosqueda et al. 2018; Shinwari et al. 2019). Microbial communities associated with seed are reported to suppress disease (Jack and Nelson 2018; Khalaf and Raizada 2018; Links et al. 2014) and directly promote plant growth (Bergna et al. 2018; Walitang et al. 2017) in cereals, fruit, vegetables, and other crops, which reveals their potential application in sustainable crop production. There is a paucity of information known about seed-associated microbiota, especially about their composition, dynamics, and assemblage (Shade et al. 2017; Wassermann et al. 2019).

Rapeseed (Brassica napus), soybean (Glycine max), and palm (Phoenix dactylifera) are the main sources of vegetable oil in the world (Liu et al. 2018). Low-erucic and low-glucosinolate edible 
rapeseed varieties are known as "canola" (Canola Council of Canada 2020). Canola is considered a staple crop in the Canadian Prairies and crucial for global food security. Its use is not limited to human consumption; canola meal is utilized in animal feeds (Good et al. 2017) and as a feedstock for biodiesel production (Ge et al. 2018). Depending on the flowering time and local adaptation, canola cultivars grow during spring or winter seasons and can be annual or biannual (Schiessl et al. 2017). Production in Western Canada is based on spring canola, with the province of Saskatchewan the largest supplier, marketing approximately 11 million metric tons from 4,955,000 ha harvested in 2018 (Statistics Canada 2020). Canola-producing areas are found in different soil and climatic zones, which represent a broad range of environments and ecological habitats (Government of Saskatchewan 2019). Despite the agricultural and nutritional importance of this oilseed, there are few studies regarding its microbiome. In addition, the few reports available mainly focused on the canola root and rhizosphere microbiomes (Bazghaleh et al. 2020; Cordero et al. 2020; Floc'h et al. 2020; Lay et al. 2018; Monreal et al. 2018), whereas the seed microbiome is poorly understood.

In agricultural crops, assembly of the seed microbiome has been linked to host genotype (Adam et al. 2018; Raj et al. 2019), field management practices (Klaedtke et al. 2016), harvesting year (Rochefort et al. 2019), or anthropogenic pollutants (Truyens et al. 2016). Nevertheless, the relative contribution of environmental factors versus host genotype is mostly unknown. In a previous study (Moreira et al. 2021), we profiled the seed microbiome of wheat (Triticum aestivum), canola (B. napus), and lentil (Lens culinaris) lines across two generations. We found that crop, genotype, and the environment were key drivers of the seed microbiome assemblage. To better understand the contribution of differences in environment, we profiled eight genetically different spring $B$. napus lines harvested from different locations in Saskatchewan, Canada. We hypothesized that the host genotype (i.e., line) would influence the $B$. napus seed microbiome structure and diversity. We further hypothesized that the collective influences of the environment (i.e., all sources of variation that are not genetic such as location and harvesting year), would have a stronger influence than genotype on the seed microbiome. To test these hypotheses, $16 \mathrm{~S}$ ribosomal RNA (rRNA) and internal transcribed spacer (ITS) amplicon libraries from seed samples collected in four site years (one location in 2016 and 2017 and two additional locations in 2017) were prepared and sequenced. Understanding how environmental and genetic factors influence the assembly of the microbiota carried by seed could provide insights into the recruitment and transmission of microbial communities in plants. This understanding is essential for implementing novel and sustainable crop breeding and agricultural management practices.

\section{MATERIALS AND METHODS}

Lines and experimental design. B. napus seed used in this study were harvested from four site years in Saskatchewan, Canada: one location (Saskatoon) in 2016 and 2017 and two additional locations (Melfort and Scott) in 2017. These three sites span a large portion of the local canola-growing regions and represent the different conditions under which canola is grown. Fields were located in the Dark Brown Soil Zone (Saskatoon, Scott; Typic Boroll) and in the Black Soil Zone (Melfort; Udic Boroll) (Table 1; Supplementary Fig. S1). At all field sites, B. napus lines were planted in a randomized complete block design experiment (plots of 6 by $2 \mathrm{~m}$ ), with three replicates. Eight lines from a nested association mapping (NAM) population were selected to represent diversity within the set (Bazghaleh et al. 2020; Taye et al. 2020): NAM 0, NAM 13, NAM 17, NAM32, NAM 37, NAM 43, NAM 72, and NAM 94. Seed planted at all fields came from the same source and were produced in hoop tents by Agriculture and AgriFood Canada (Saskatoon, SK, Canada). All seed samples analyzed in this study were stored in paper bags at $21^{\circ} \mathrm{C}$ (room temperature) until analysis. DNA extraction of seed samples collected from each site year was carried out approximately 8 months after harvesting. Library preparation and Illumina sequencing were done in two batches for each gene. Samples from Saskatoon 2016, Saskatoon 2017, and Melfort 2017 comprised the first batch. Scott 2017 were processed separately due to a delayed harvest (Table 1; Supplementary Fig. S1) and subsequent delays in obtaining the seed.

DNA extraction and high-throughput amplicon sequencing. A modified protocol previously described by Rastogi et al. (2010) and Martins et al. (2013) was applied for DNA extraction of the seed epiphytic microbial communities. From each plot harvested, $5 \mathrm{~g}$ of seed was immersed in $25 \mathrm{ml}$ of buffered wash solution containing $0.024 \%$ Triton, $10 \mathrm{mM}$ EDTA, and $20 \mathrm{mM}$ Tris- $\mathrm{HCl}$ in a $250-\mathrm{ml}$ Erlenmeyer flask and shaken $(150 \mathrm{rpm})$ for $15 \mathrm{~min}$ at room temperature. A 0.22- $\mu$ m membrane (Pall, Mexico) was used to filter the solution followed by DNA extraction with the DNeasy PowerWater

\begin{tabular}{|c|c|c|c|c|c|c|c|}
\hline \multicolumn{8}{|c|}{$\begin{array}{c}\text { TABLE } 1 \\
\text { Saskatchewan, Canada field sites }\end{array}$} \\
\hline Location & Year & GPS coordinates & Soil $^{\mathrm{a}}$ & Seeding & Harvesting & Precip $(\mathrm{mm})^{\mathrm{b}}$ & Temp $\left({ }^{\circ} \mathrm{C}\right)^{\mathrm{C}}$ \\
\hline Saskatoon & 2017 & $\begin{array}{l}52^{\circ} 10^{\prime} 59.336^{\prime \prime} \mathrm{N} \\
106^{\circ} 30^{\prime} 53.654^{\prime \prime} \mathrm{W}\end{array}$ & $\begin{array}{l}\text { Dark Brown Chernozem } \\
\text { (Typic Boroll), clay, loam texture, } \\
\text { pH } 7.5, \text { OM 5.1\% }\end{array}$ & 28-29 May & 5-28 August & 81.6 & 17.5 \\
\hline Melfort & 2017 & $\begin{array}{l}52^{\circ} 49^{\prime} 9.599^{\prime \prime} \mathrm{N} \\
104^{\circ} 35^{\prime} 46.852^{\prime \prime} \mathrm{W}\end{array}$ & $\begin{array}{l}\text { Black Chernozem } \\
\text { (Udic Boroll), silty clay } \\
\text { texture, pH } 6.4 \text {, OM 8.2\% }\end{array}$ & 19 May & 9 September & 92.5 & 16.6 \\
\hline Scott & 2017 & $\begin{array}{l}52^{\circ} 21^{\prime} 55.332^{\prime \prime} \mathrm{N} \\
108^{\circ} 52^{\prime} 32.555^{\prime \prime} \mathrm{W}\end{array}$ & $\begin{array}{l}\text { Dark Brown Chernozem (Typic Boroll), } \\
\text { loam texture, pH 5.7, OM 5.8\% }\end{array}$ & 20 June & 17 October & 106.2 & 13.7 \\
\hline \multicolumn{8}{|c|}{$\begin{array}{l}\text { a } \mathrm{OM}=\text { organic matter. } \\
\text { b Precipitation during growing season. } \\
\text { c Mean temperature. } \\
\text { d Foster et al. (2014). } \\
\text { e Bedard-Haughn et al. (2013) and Arcand et al. (2016). }\end{array}$} \\
\hline
\end{tabular}


Kit (Qiagen, Hilden, Germany) and quantification in a Qubit Fluorometer (Invitrogen, Carlsbad, CA, U.S.A.). Bacterial 16S rRNA and fungal ITS regions were amplified using the primer sets with Illumina adapters 342F/806R (Mori et al. 2014) and ITS1F_KYO1/ITS2-R_KYO2 (Toju et al. 2012), respectively. PCR assays were carried out using DreamTaq Hot Start DNA Polymerase (Thermo Scientific, Carlsbad, CA, U.S.A.) for 16S rRNA, and HotStarTaq Master Mix Kit (Qiagen) for ITS amplifications in a T100 Thermal cycler (Bio-Rad, Hercules, CA, U.S.A.) (Moreira et al. 2021). NucleoMag magnetic beads (NucleoMag NGS Cleanup and size select; Macherey-Nagel, Düren, Germany) were used to purify PCR products followed by barcoding with Nextera XT Index Kit v2 (Illumina Inc., San Diego, CA, U.S.A.) using KAPA HiFi HotStart ReadyMix (KAPA Biosystems, Wilmington, MA, U.S.A.). Libraries were sequenced in an Illumina MiSeq platform with the MiSeq Reagent Kit v3 (600 cycles) for bacteria and MiSeq Reagent Kit v2 (500 cycles) for fungi. Negative controls were included in the library preparation.

Bioinformatics and statistical analysis. Cutadapt v.2.1 was used for removing primers (Martin 2011). Sequences were processed in QIIME2 v.2019.10 (Bolyen et al. 2019), quality filtered, and assigned to amplicon sequence variants (ASVs) in Deblur (bacteria) (Amir et al. 2017) and DADA2 (fungi) (Callahan et al. 2016), in accordance with a standardized protocol developed for soil, rhizosphere, root, leaf, and seed microbiome analyses (Bazghaleh et al. 2020). A 342F/806R-trained V3/V4 SILVA database v.132 (Quast et al. 2013) and UNITE database v.8.0. (Abarenkov et al. 2010) were used to classify bacterial and fungal ASVs, respectively.

Data analyses were conducted in R v.4.0 using the Phyloseq package v.1.32.0 (McMurdie and Holmes 2013) for $\alpha$ - and $\beta$ diversity metrics. Differences in $\alpha$-diversity values (Chao 1 , inverse Simpson's) were tested using generalized linear models in the car package v.3.0.8 (Fox et al. 2020) followed by Tukey's posthoc tests in the multcomp package v.1.4.13 (Hothorn et al. 2020). Multidimensional ordinations using principal coordinates analyses (PCoA) were performed on Bray-Curtis (Hellinger-transformed) dissimilarities to assess microbial community structure. To test whether seed microbial communities were significantly affected by environment or B. napus line, permutational multivariate analysis was carried out in the Vegan package v.2.5.6. (Oksanen et al. 2019) with the function adonis. Vegan was also used to obtain relative abundance of bacterial and fungal taxa. To identify taxa with differential abundance among environments, the analysis of composition of microbiomes (ANCOM) in QIIME2 was applied (Mandal et al. 2015).

We use the term "core microbiome" to describe the ASVs present in every B. napus line and replicate analyzed in this study and in individual site years. Separate comparisons describe the taxonomy (class, order, family, and genus) of bacterial and fungal ASVs detected within a given site year. These comparisons highlight taxa that were common across different environments without necessarily being the exact ASV match.

Data deposition. Sequence data were deposited in the NCBI Sequence Read Archive, Bioproject ID PRJNA563687, accessions SAMN14541915 to SAMN14542010.

\section{RESULTS}

In total, 1,401,178 bacterial and 4,267,381 fungal reads were assigned to 3,000 and 1,765 ASVs, respectively (Table 2; Supplementary Fig. S2). $\alpha$-Diversity estimators differed between 2016 and 2017 at the Saskatoon field location $(P<0.05)$. Specifically, bacterial and fungal diversity as well as bacterial richness were higher in 2016 (Fig. 1; Supplementary Table S1). Similarly, differences were detected between the three locations in 2017, where Melfort exhibited the highest richness and diversity for both bacterial and fungal microbial communities (Fig. 1; Supplementary Table S2). Comparisons within individual locations showed that $B$. napus line also significantly affected $\alpha$ diversity. For instance, in 2017 at Melfort and Saskatoon, line NAM 0 showed pronounced differences in fungal diversity when compared with other lines but the patterns were not consistent between locations or between years at the Saskatoon site (Fig. 1; Supplementary Tables S1 and S2).

PCoA plots based on Bray Curtis dissimilarity revealed a clear clustering of bacterial and fungal communities depending upon year (Fig. 2A and B) and location (Fig. 2C and D). Permutational multivariate analysis of bacterial and fungal communities corroborated that year and location (i.e., environmental conditions) $(P<$ $0.05)$ were the main factors explaining the variation in the microbial community structure, with a significant interaction year $\times$ line and location $\times$ line for fungi but not for bacteria (Table 3 ). Thus, year explained $20 \%$ of the bacterial variance and $32 \%$ of the fungal variance. Similarly, location accounted for $34 \%$ of the bacterial variance and $43 \%$ of the fungal variance. Year and location interactions with line represented 18 and $26 \%$, respectively, of the variance for fungal communities (Table 3 ). When all four site years were assessed separately, B. napus line accounted for 42 to $83 \%$ of the fungal variance within a given site year. Furthermore, Melfort 2017 was the only field where line did not explain bacterial community structure (Table 3 ).

Relative abundance of the predominant bacterial and fungal orders $(>1 \%)$ detected in the B. napus seed microbiome fluctuated between 2016 and 2017 in Saskatoon and among locations in 2017 (Fig. 3; Supplementary Tables S3 to S10). However, all site years had high relative abundance of Gammaproteobacteria orders

TABLE 2

Summary of amplicon sequence variants (ASVs) found in the seed microbiome of Brassica napus across years and locations

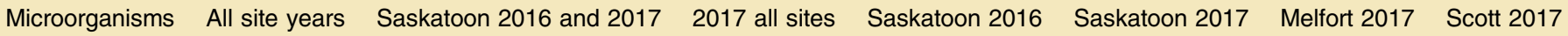

\begin{tabular}{crrrrrrr}
\hline Bacteria & & & & & \\
\hline Total & 3,000 & 1,806 & 2,555 & 1,299 & 1,063 & 2,165 & 434 \\
\hline Core $^{a}$ & 2 & 4 & 2 & 18 & & 6 & \\
\hline Fungi & & & & & & & \\
\hline Total & 1,765 & 1,082 & 1,425 & 619 & 675 & 901 & 308 \\
\hline Core $^{\text {a }}$ & 11 & 25 & 11 & 32 & 26 & 19 \\
\hline
\end{tabular}

a ASVs found in every sample and replicate examined. 
Enterobacteriales and Pseudomonadales and Dothideomycetes orders Pleosporales and Capnodiales. Differential abundance analysis using ANCOM showed that members of the Enterobacteriales order substantially increased while Xanthomonadales and Entylomatales substantially decreased between 2016 and 2017 at the Saskatoon location (Supplementary Tables S3 and S4). Among the three locations sampled in 2017, Melfort showed a high relative abundance of members of the bacterial order Propionibacteriales (Supplementary Tables S5, S6, and S7). Similarly, Scott exhibited a higher relative abundance of members of the fungal order Hypocreales whereas, at Melfort, the orders Tremellales and Sporidiobolales had higher relative abundance than at other locations (Supplementary Tables S8, S9, and S10).

Further analysis revealed the existence of a "core microbiome" present in every replicate, line, year, and location examined; this core included 2 bacterial and 11 fungal ASVs (Table 2). In addition, ASVs that were present in every sample within a site also belonged to common taxonomic groups across all site years. These included members of the bacterial orders Enterobacteriales, Pseudomonadales, Micrococcales, and Sphingomonadales as well as members

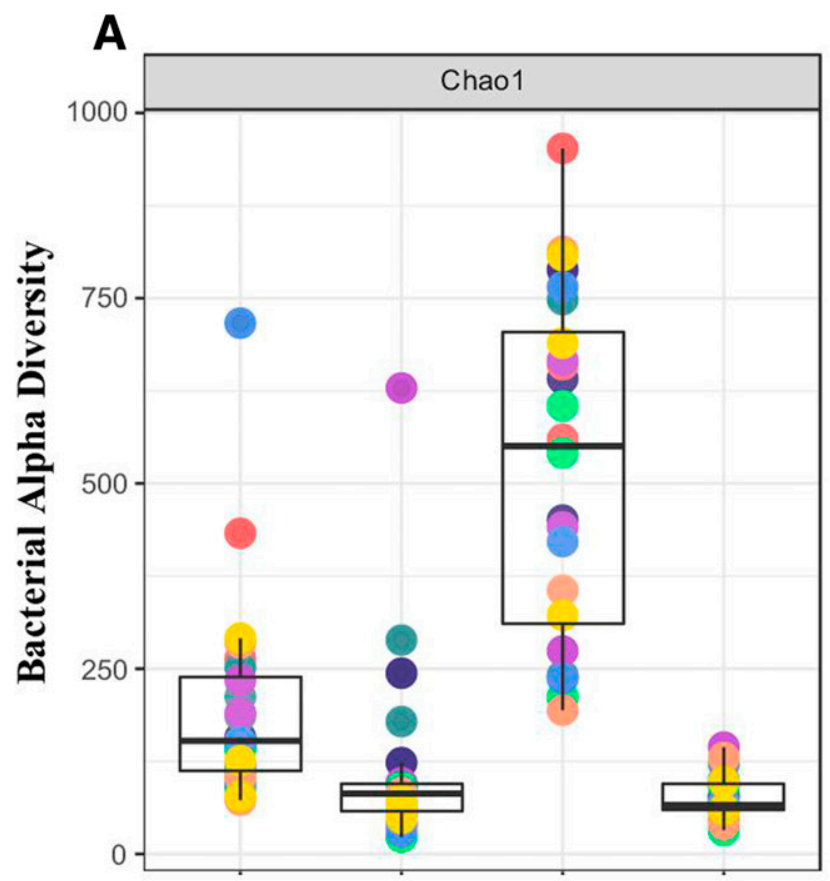

B

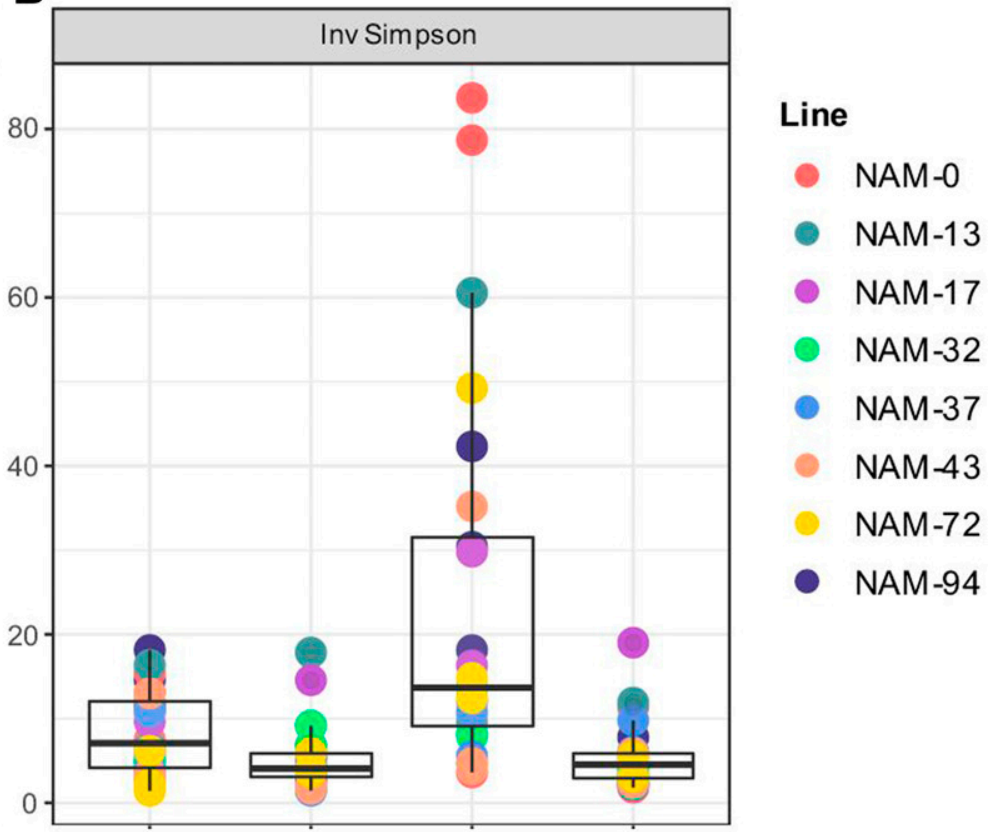

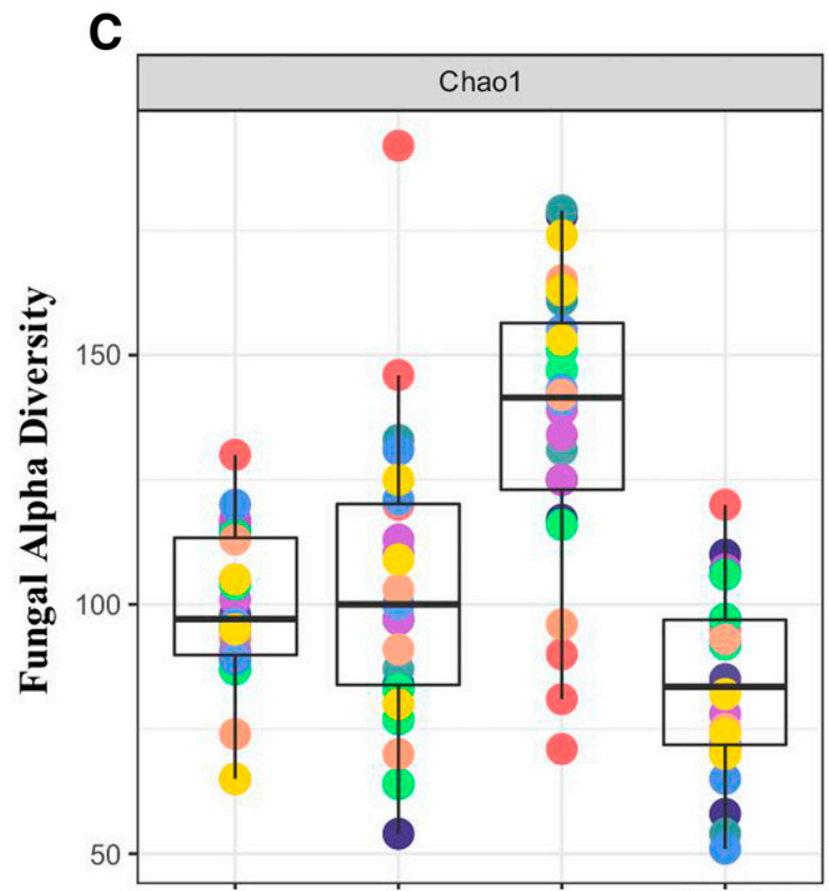

SK.2016 SK.2017 MF.2017 SC.2017
D

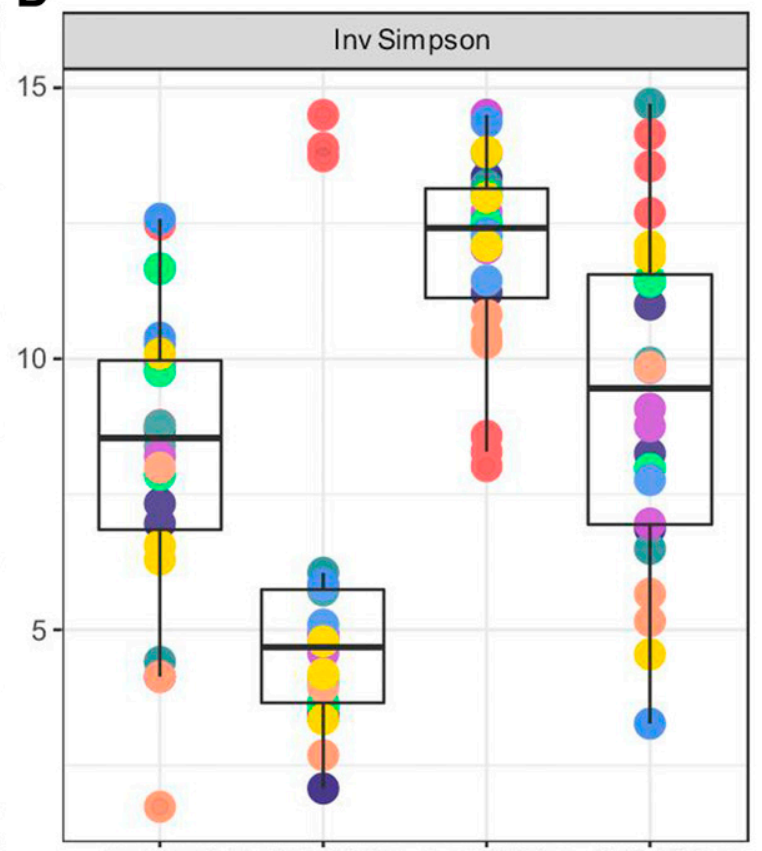

SK.2016 SK.2017 MF.2017 SC.2017

Fig. 1. $\alpha$-Diversity measures of $\mathbf{A}$ and $\mathbf{B}$, bacterial and $\mathbf{C}$ and $\mathbf{D}$, fungal communities associated with canola seed harvested in Saskatchewan. $\mathrm{NAM}=$ nested association mapping population 
of the fungal orders Pleosporales, Capnodiales, Tremellales, Filobasidiales, and Sporidiobolales (Table 4). More specifically, Pseudomonas spp., Alternaria spp., Chalastospora gossypii, Mycosphaerella tassiana, Vishniacozyma victoriae, Dioszegia hungarica, and Stemphylium vesicarium were found in all site years.

\section{DISCUSSION}

Environmental and genetic factors have been reported to shape the roots and rhizosphere microbiomes (Edwards et al. 2015; Liu et al. 2019; Simonin et al. 2020); however, their effect on other plant organs is poorly understood. Environmental conditions differ across sites and years as realized through contrasts in climate or weather as well as differences in soil type and resulting fertility. We analyzed the contribution of environment and genotype (line) in the B. napus seed-associated microbiota assemblage. Bacterial and fungal communities associated with eight $B$. napus lines were assessed in four different site years, 2 years in Saskatoon (2016 and 2017) and two additional locations in 2017 (Melfort and Scott). We confirmed that environment (i.e., site year) significantly affected bacterial and fungal community assemblages, reflecting that environmental conditions, including biotic or abiotic components and weather, predominantly determine the seed microbiome. For example, precipitation was greater in 2016 than 2017 at the Saskatoon site, which may explain the differences in the seed microbial community structure, including richness and diversity indices (Allard et al. 2020; Mavrodi et al. 2018). Year-to-year differences in the seed microbiome were previously described in winter oilseed rape (Rochefort et al. 2019) and radish (Rezki et al. 2018). In both studies, fungi were more affected by differences between years than bacteria, supporting our findings in spring B. napus.

Geographical location is known to shape the microbial composition of different plant organs in several crops (Barnett et al. 2015; Gdanetz and Trail 2017; Kim et al. 2018; Walters et al. 2018), including seed (Klaedtke et al. 2016; Walitang et al. 2018). Studies with bean (Phaseolus vulgaris L.) (Klaedtke et al. 2016) and barley (Hordeum vulgare) (Chen et al. 2016) confirmed that there is a sitespecific effect linked to human practices and environmental conditions that determines microbial load and diversity in the seed microbiome. In the study carried out with barley seed, Chen et al. (2016) reported that harvesting method and harvesting date had a significant impact on the fungal community composition. Similar to our study, this work was carried out in Western Canada, including sites in Saskatchewan.
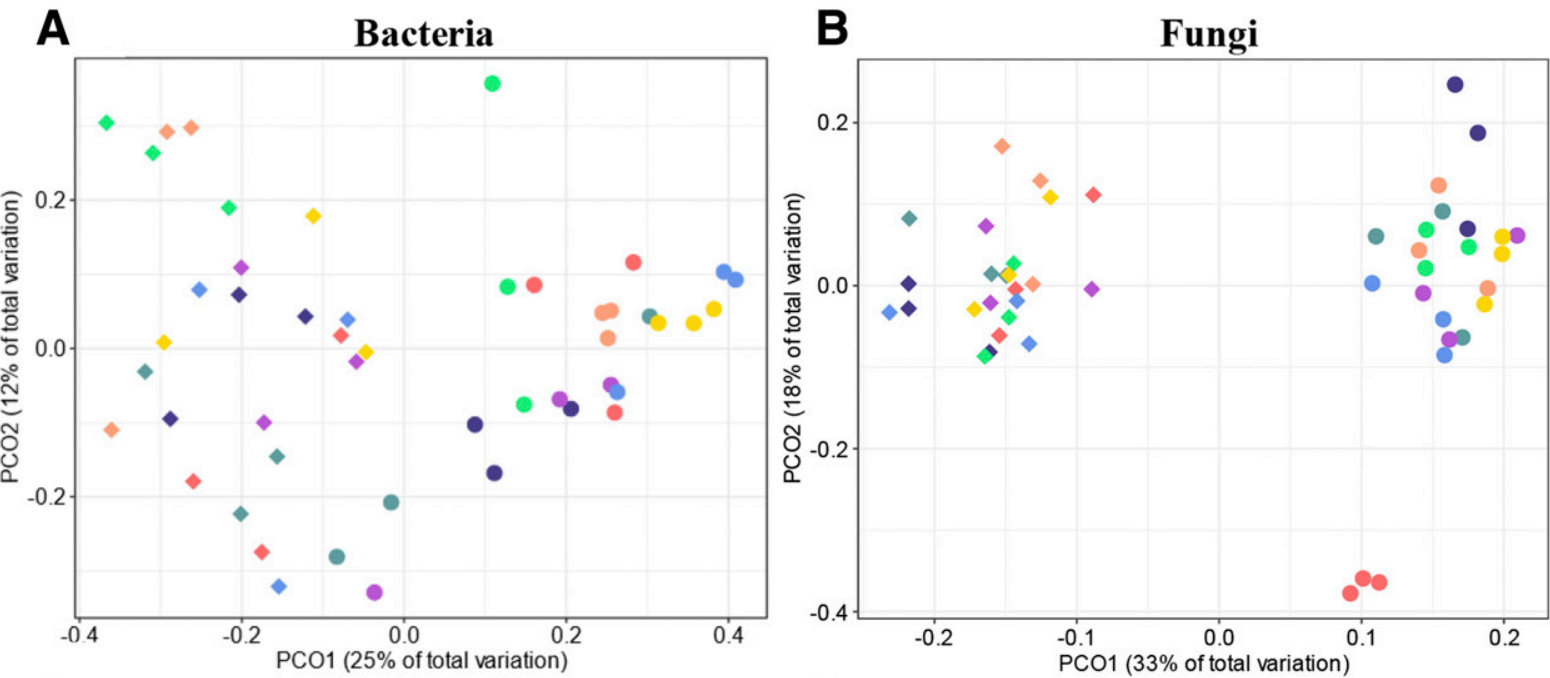

Year (in Saskatoon)

- 2016

- 2017

Line

- NAM-O

- NAM-13

- NAM-17

- NAM-32

- NAM-37

- NAM-43

- NAM-72

- NAM-94

\section{C}

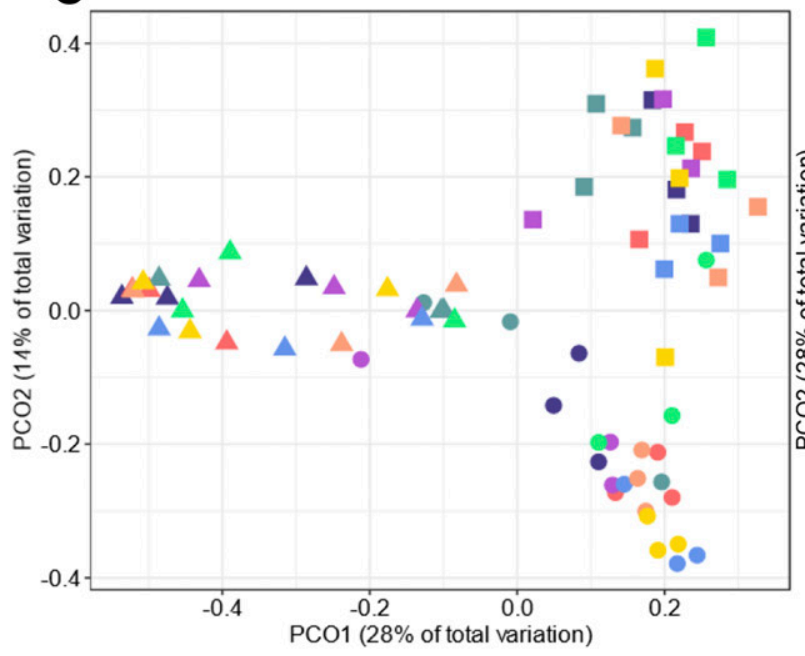

D

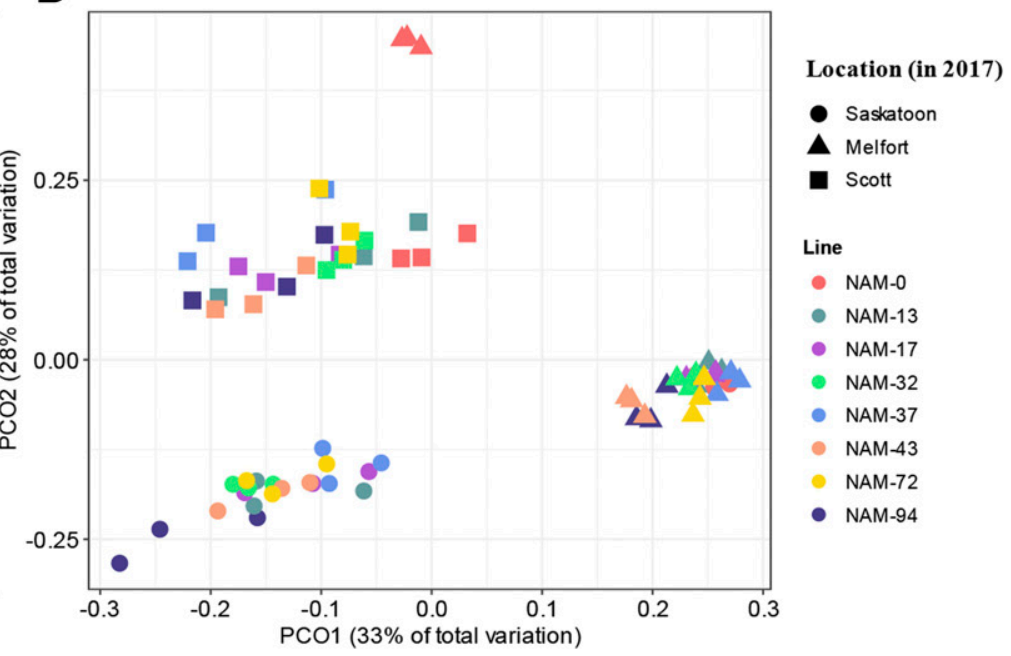

Fig. 2. Principal coordinate analysis (PCOA) based on Bray-Curtis index of bacterial and fungal amplicon sequence variants from canola seed harvested across $\mathbf{A}$ and $\mathbf{B}, 2$ years and $\mathbf{C}$ and $\mathbf{D}$, three locations in Saskatchewan. NAM = nested association mapping population. 
Although the direct impact of soil type, $\mathrm{pH}$ or organic matter on the seed microbiota has not been described in the literature, findings in below- and aboveground microbiomes could give us an insight into how these properties influence seed. Previous reports suggest the presence of a communication network within plant organs, in which spermosphere, rhizosphere, and phyllosphere communities interact (Hassani et al. 2018; Lemanceau et al. 2017). Thus, microbial shifts in one organ will be reflected in the whole phytobiome. Soil type is characterized by different physicochemical properties that, together with root exudates, mediate the formation of unique and localized microenvironments and, consequently, microbial community structures (Berg and Smalla 2009; Lloyd et al. 2016). Experiments carried out in the Canadian Prairies by Lay et al. (2018) and Cordero et al. (2020) showed the effect of location and soil type on bacterial communities in canola roots and rhizosphere. Our study of the seed microbiome included fields in Dark Brown (Saskatoon and Scott) and Black (Melfort) soil zones that differed not only in soil texture but also in $\mathrm{pH}$ and organic matter content. These parameters could indirectly affect seed microbial assembly by causing differences in the soil microbiome which can act as an inoculum source for the seed (Nelson 2018). Among all soil characteristics, $\mathrm{pH}$ was documented in the literature as the key factor for bacterial community composition and diversity, being involved in numerous biogeochemical processes and, consequently, altering bacterial growth (Hartman et al. 2008; Lauber et al. 2009). Trials with maize (Zea mays L.) (Tan et al. 2020), soybean (G. max) (Zhang et al. 2018), wheat (T. aestivum) (Fan et al. 2018; Simonin et al. 2020), and canola (Cordero et al. 2020) showed that $\mathrm{pH}$ regulates microbial assemblage in rhizospheric and bulk soils. In our seed study, the Scott site was characterized by low $\mathrm{pH}$ (approximately 5). In contrast, Melfort was not only more alkaline ( $\mathrm{pH}$ 6.4) than Scott but also had much higher organic matter content $(8.2$ versus $5.8 \%$ ), which may have contributed to the highest richness and diversity levels found in both bacterial and fungal communities at Melfort. The correlation between organic matter content and bacterial load in roots and aerial tissues was reported before by Haron et al. (2019), who indicated that variations in soil organic matter result in different plant-associated microbial communities.

Host genotype effect on the phytobiome assemblage has been examined before in oilseed crops, including soybean (Liu et al. 2019; Zhong et al. 2019), sunflower (Helianthus annuus) (Leff et al. 2017), olive (Olea europaea L.) (Mina et al. 2020), and canola (Taye et al. 2020); however, only two studies considered the effect of the host genotype on the B. napus seed microbiome. Endophytic and epiphytic studies with winter rapeseed revealed a cultivarspecific effect for both bacterial and fungal seed microbiomes (Rochefort et al. 2019; Rybakova et al. 2017). When canola fields were assessed in our study, a higher plant line effect was observed in fungi than in bacteria. Our results are supported by a seed microbiome analysis carried out in different plants of the Brassicaceae family (Barret et al. 2015), where the host primarily affected the fungal community composition. In addition, the geographical location of the production region highly affects fungal assemblage (Barret et al. 2016). The lack of seed microbiome studies considering fungi impedes a deeper analysis of the host impact. According to Andreo-Jimenez et al. (2019), an active recruitment of fungal species by the plant host can occur to cope with or as a result of stress conditions; in some cases, fungi colonizes the plant to escape environmental stress.

Our results demonstrated the presence of microbial taxa shared between all lines and fields examined. Pseudomonas spp. as well as members of the Sphingomonadales order, previously reported as part of the core seed microbiome in B. napus (Links et al. 2014; Rochefort et al. 2019), were among the bacterial taxa found in every single sample in our work. In wheat cultivars, Pseudomonas spp. were detected in several stages of plant development, from seed to leaf formation, suggesting that they play a critical role in plant fitness due to their ability to move systemically throughout the plant (Kuźniar et al. 2020). Furthermore, Pseudomonas and Sphingomonas strains isolated from rice (Oryza sativa) seed exhibited plant

TABLE 3

Permutational multivariate analysis of the microbial communities associated with Brassica napus lines

\begin{tabular}{|c|c|c|c|c|c|c|}
\hline Site & \multicolumn{3}{|c|}{ Bacteria } & \multicolumn{3}{|c|}{ Fungi } \\
\hline \multicolumn{7}{|c|}{ Saskatoon (2016 and 2107) } \\
\hline Line & 1.22 & 0.18 & 0.093 & 1.30 & 0.19 & 0.102 \\
\hline Year $\times$ line & 1.23 & 0.13 & 0.076 & 2.52 & 0.18 & 0.001 \\
\hline Location & 18.00 & 0.34 & 0.001 & 25.87 & 0.43 & 0.001 \\
\hline Line & 0.95 & 0.09 & 0.607 & 1.33 & 0.13 & 0.081 \\
\hline Location $\times$ line & 1.13 & 0.14 & 0.172 & 4.86 & 0.26 & 0.001 \\
\hline \multicolumn{7}{|l|}{ Saskatoon 2016} \\
\hline Line & 1.41 & 0.38 & 0.012 & 1.64 & 0.42 & 0.001 \\
\hline Line & 1.04 & 0.31 & 0.414 & 11.52 & 0.83 & 0.001 \\
\hline \multicolumn{7}{|l|}{ Scott 2017} \\
\hline Line & 1.29 & 0.36 & 0.055 & 2.05 & 0.47 & 0.001 \\
\hline
\end{tabular}


growth promotion traits, including siderophore production (Ruiza et al. 2011; Walitang et al. 2017). The Dioszegia hungarica fungus was also part of the core taxa. This Basidiomycota has been described in rice seed (Eyre et al. 2019), wheat seed (Nicolaisen et al. 2014), and wheat leaves (Ricks and Koide 2019) and is reported to be involved in suppression of plant pathogens (Hassani et al. 2018). Alternaria spp., C. gossypii, M. tassiana, and S. vesicarium, described in the literature as plant pathogens, were also identified here as part of the core seed microbiome. Alternaria spp. are known for causing dark spot disease on Brassica leaves (Kumar et al. 2014). Moreover, members of this genus are associated with spoilage and mycotoxin production (Bhat and Reddy 2017). Further investigation into relationships among organisms (e.g., between bacteria and fungi) can be explored to determine whether there are potential antagonistic interactions occurring that benefit plant health. For instance, Links et al. (2014) found Pantoea spp. in T. aestivum seed able to suppress Alternaria spp.

$B$. napus seed mainly contained members of the Enterobacteriales, Pseudomonadales, and Pleosporales bacterial orders (Barret et al. 2015; Links et al. 2014). Although Betaproteobacteriales has been reported as one of the major orders colonizing winter rapeseed (Rochefort et al. 2019; Rybakova et al. 2017), we did not find the same pattern on spring B. napus. Scott received the highest precipitation across all 2017 sites which, added to a delayed harvest, could explain the notable occurrence of the Hypocreales order (Paul et al. 2004). A high incidence of yeasts belonging to the Tremellales order was noticed in Melfort, possibly related to high soil organic matter content. Tremellales are basidiomycetes, which play a key role in the decomposition of organic matter (Banerjee et al. 2019; Ottesen et al. 2016). The observed shifts in microbial community composition across years and locations are driven by environment and host genotype. These shifts may also reflect plant fitness and resilience against biotic and abiotic stresses, which directly affect yield and productivity (Berg and Raaijmakers 2018; Singh and Trivedi 2017).

Acquisition, survival, and transmission of seed-associated microorganisms are determined by the mother plant (vertical transmission) as well as by agricultural management practices, weather, and seed storage conditions (horizontal transmission) (Barret et al. 2016; Singh and Mathur 2004). Our findings determined that environment and genotype influence the seed microbiome assemblage in spring B. napus. However, the environment appears to play a more significant role in shaping seed-associated microbial communities. Nevertheless, the existence of a core microbial taxa

A
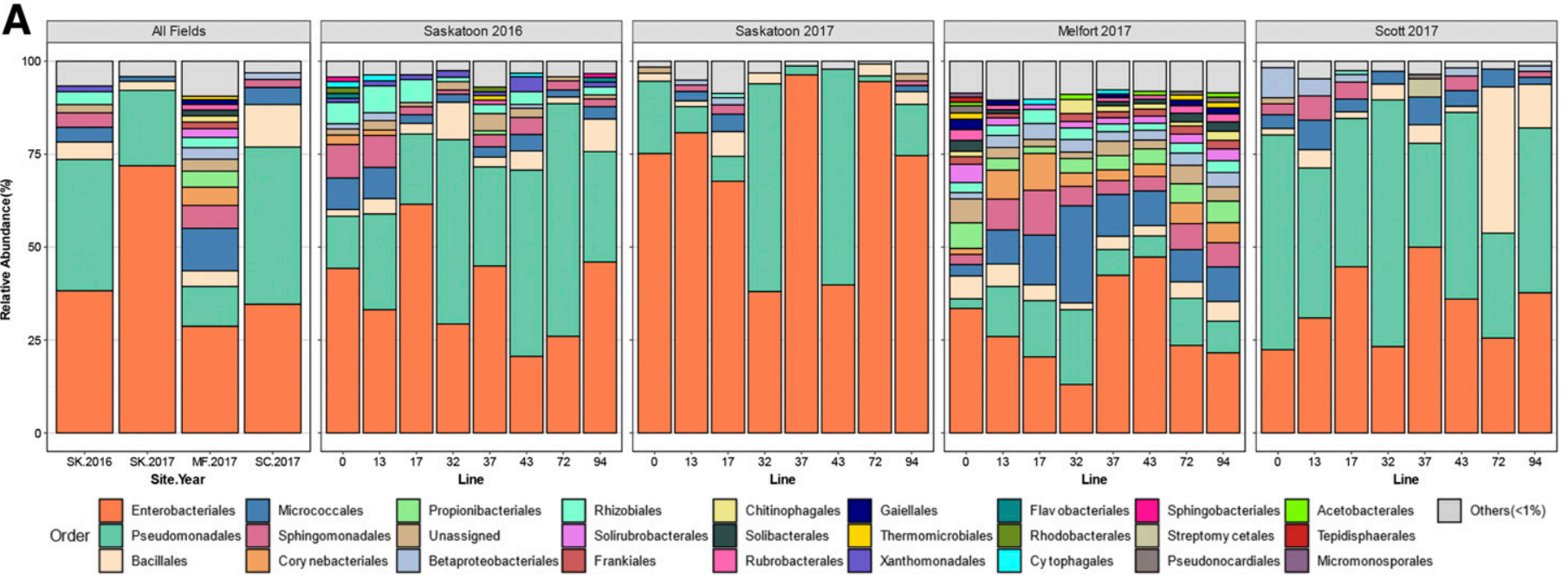

B
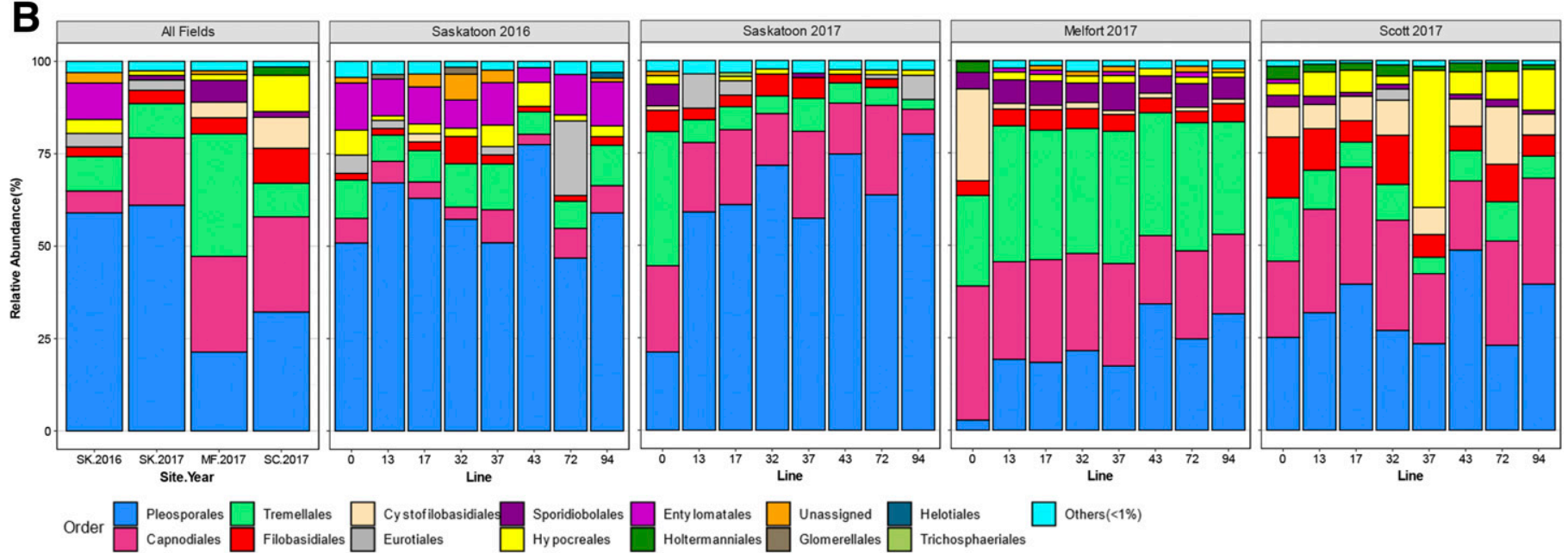

Fig. 3. Relative abundance of the dominant A, bacterial and B, fungal orders in the seed microbiome of Brassica napus lines across years and locations. 
TABLE 4

Taxonomic assignment of the bacterial and fungal amplicon sequence variants (ASVs) shared among all Brassica napus lines within a location $^{\mathrm{a}}$

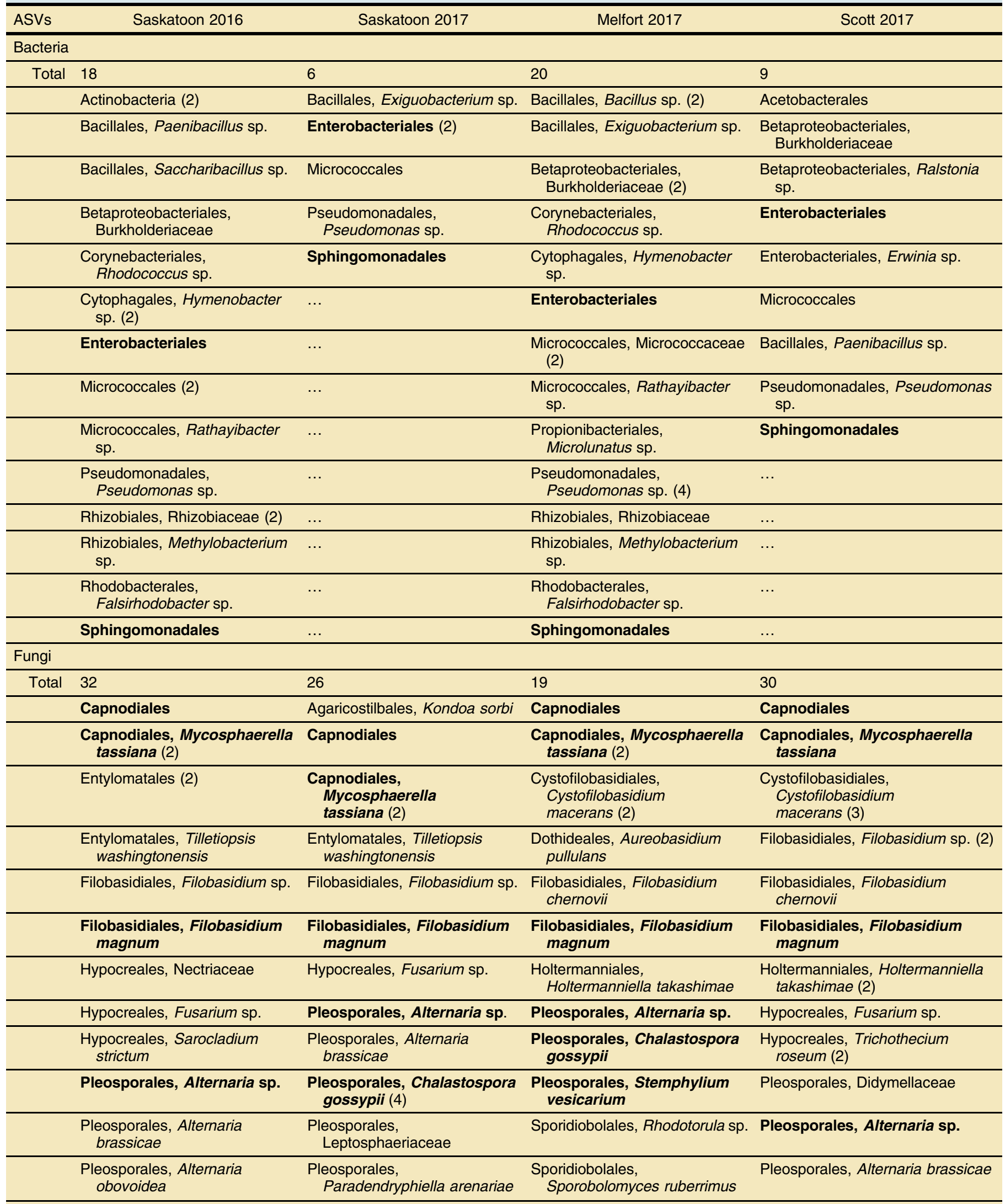

(Continued on next page)

a Taxa in bold denote members of the "core microbiome" found across locations. Total = number of bacterial and fungal ASVs found in every sample and replicate examined (per site). 
TABLE 4 (Continued from previous page)

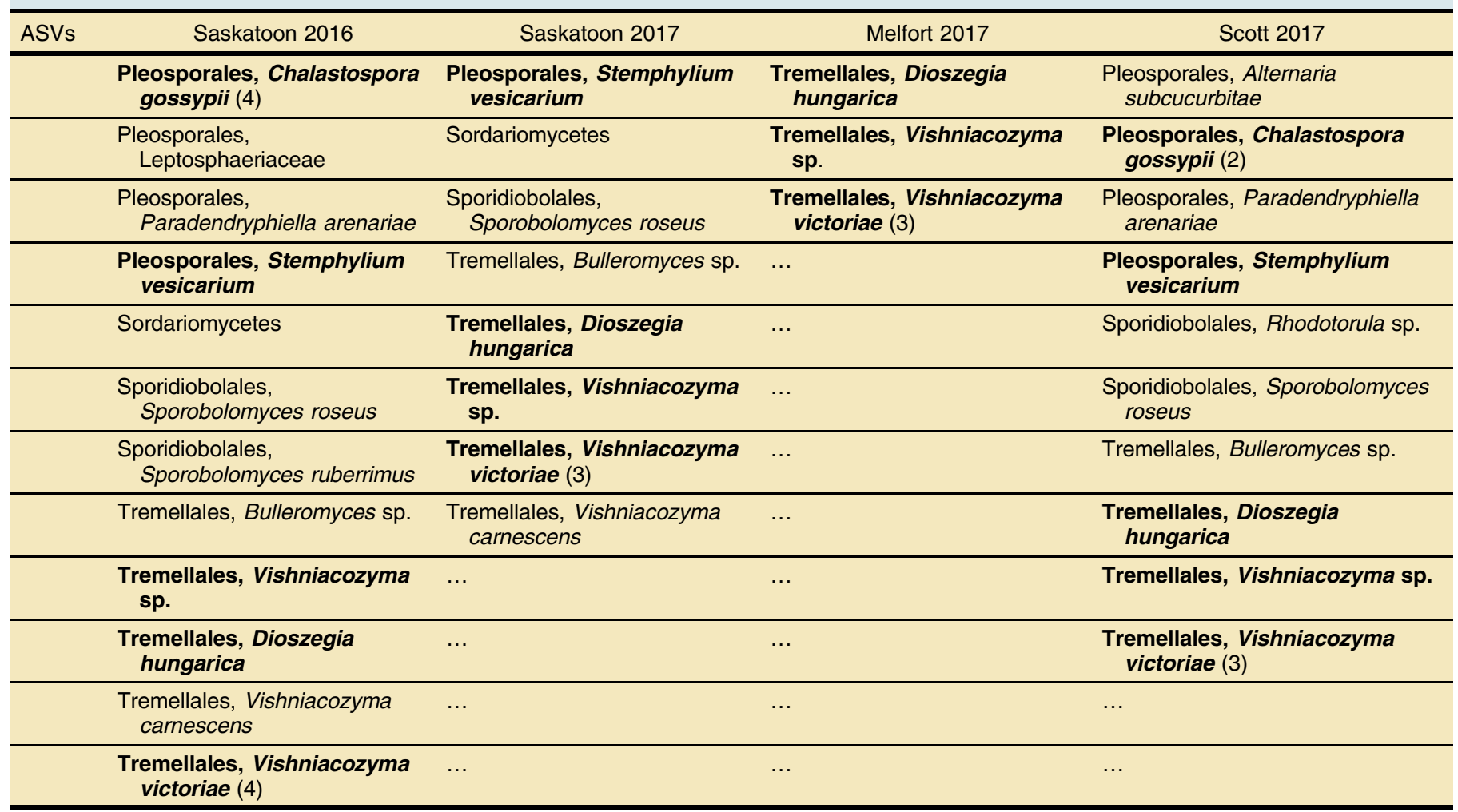

implies that $B$. napus plants recruit and carry bacterial and fungal species that could interact with further generations, affecting plant fitness in novel environments. Further research should consider the impacts of plant genotype $\times$ environment interactions on the entire plant microbiome (i.e., the phytobiome), with special focus on optimization in plant breeding.

\section{ACKNOWLEDGMENTS}

We thank S. Vail, I. Parkin, S. Siciliano, S. Mamet, N. Bazghaleh, C. Norris, A. Schebel, J. Bell, and S. Ryu for their valuable support and suggestions. We also thank Agriculture and Agri-Food Canada (AAFC) and the College of Agriculture and Bioresources at University of Saskatchewan.

\section{LITERATURE CITED}

Abarenkov, K., Henrik Nilsson, R., Larsson, K.-H., Alexander, I. J., Eberhardt, U., Erland, S., Høiland, K., Kjøller, R., Larsson, E., Pennanen, T., Sen, R., Taylor, A. F. S., Tedersoo, L., Ursing, B. M., Vrålstad, T., Liimatainen, K., Peintner, U., and Kõljalg, U. 2010. The UNITE database for molecular identification of fungi-recent updates and future perspectives. New Phytol. 186:281-285.

Adam, E., Bernhart, M., Müller, H., Winkler, J., and Berg, G. 2018. The Cucurbita pepo seed microbiome: Genotype-specific composition and implications for breeding. Plant Soil 422:35-49.

Allard, S. M., Ottesen, A. R., and Micallef, S. A. 2020. Rain induces temporary shifts in epiphytic bacterial communities of cucumber and tomato fruit. Sci. Rep. 10:1765.

Amir, A., McDonald, D., Navas-Molina, J. A., Kopylova, E., Morton, J. T., Xu, Z. Z., Kightley, E. P., Thompson, L. R., Hyde, E. R., Conzalez, A., and Knight, R. 2017. Deblur rapidly resolves single-nucleotide community sequence patterns. mSystems 2:e00191-16.

Andreo-Jimenez, B., Vandenkoornhuyse, P., Lê Van, A., Heutinck, A., Duhamel, M., Kadam, N., Jagadish, K., Ruyter-Spira, C., and Bouwmeester,
H. 2019. Plant host and drought shape the root associated fungal microbiota in rice. PeerJ 7:e7463.

Andreote, F. D., and Pereira e Silva, M. C. 2017. Microbial communities associated with plants: Learning from nature to apply it in agriculture. Curr. Opin. Microbiol. 37:29-34.

Arcand, M. M., Helgason, B. L., and Lemke, R. L. 2016. Microbial crop residue decomposition dynamics in organic and conventionally managed soils. Appl. Soil Ecol. 107:347-359.

Arunkumar, N., Rakesh, S., Rajaram, K., Kumar, N. R., and Durairajan, S. S. K. 2019. Anthosphere microbiome and their associated interactions at the aromatic interface. Pages 309-324 in: Plant Microbe Interface. A. Varma, S. Tripathi, and R. Prasad, eds. Springer, Cham, Switzerland.

Banerjee, S., Walder, F., Büchi, L., Meyer, M., Held, A. Y., Gattinger, A., Keller, T., Charles, R., and van der Heijden, M. G. A. 2019. Agricultural intensification reduces microbial network complexity and the abundance of keystone taxa in roots. ISME J. 13:1722-1736.

Barnett, B. A., Holm, D. G., Koym, J. W., Wilson, R. G., and Manter, D. K. 2015. Site and clone effects on the potato root-associated core microbiome and its relationship to tuber yield and nutrients. Am. J. Potato Res. 92:1-9.

Barret, M., Briand, M., Bonneau, S., Préveaux, A., Valière, S., Bouchez, O., Hunault, G., Simoneau, P., and Jacques, M.-A. 2015. Emergence shapes the structure of the seed microbiota. Appl. Environ. Microbiol. 81:1257-1266.

Barret, M., Guimbaud, J. F., Darrasse, A., and Jacques, M. A. 2016. Plant microbiota affects seed transmission of phytopathogenic microorganisms. Mol. Plant Pathol. 17:791-795.

Bazghaleh, N., Bell, J. K., Mamet, S. D., Moreira, Z. M., Taye, Z. M., Williams, S., Norris, C., Dowhy, T., Arcand, M., Lamb, E. G., Links, M., Shirtliffe, S., Vail, S., Siciliano, S. D., and Helgason, B. 2020. An intensive multilocation temporal dataset of fungal and bacterial communities in the root and rhizosphere of Brassica napus. Data Brief 31:106143.

Bedard-Haughn, A., Comeau, L. P., and Sangster, A. 2013. Gross nitrogen mineralization in pulse-crop rotations on the Northern Great Plains. Nutr. Cycl. Agroecosyst. 95:159-174.

Berg, G., and Raaijmakers, J. M. 2018. Saving seed microbiomes. ISME J. 12: 1167-1170.

Berg, G., and Smalla, K. 2009. Plant species and soil type cooperatively shape the structure and function of microbial communities in the rhizosphere. FEMS Microbiol. Ecol. 68:1-13. 
Bergna, A., Cernava, T., Grosch, R., Zachow, C., and Berg, G. 2018. Tomato seeds preferably transmit plant beneficial endophytes. Phytobiomes J. 2: 183-193.

Bhat, R., and Reddy, K. R. N. 2017. Challenges and issues concerning mycotoxins contamination in oil seeds and their edible oils: Updates from last decade. Food Chem. 215:425-437.

Bolyen, E., Rideout, J. R., Dillon, M. R., Bokulich, N. A., Abnet, C. C., AlGhalith, G. A., et al. 2019. Reproducible, interactive, scalable and extensible microbiome data science using QIIME 2. Nat. Biotechnol. 37: 852-857.

Callahan, B. J., McMurdie, P. J., Rosen, M. J., Han, A. W., Johnson, A. J. A., and Holmes, S. P. 2016. DADA2: High-resolution sample inference from Illumina amplicon data. Nat. Methods 13:581-583.

Canola Council of Canada. 2020. Canola oil fact and fiction. https:// www.canolacouncil.org/about-canola/oil/\#fact-and-fiction

Chen, W., Turkington, T. K., Lévesque, C. A., Bamforth, J. M., Patrick, S. K., Lewis, C. T., Chapados, J. T., Gaba, D., Tittlemier, S. A., MacLeod, A., and Gräfenhan, T. 2016. Geography and agronomical practices drive diversification of the epiphytic mycoflora associated with barley and its malt end product in western Canada. Agric. Ecosyst. Environ. 226:43-55.

Cordero, J., De Freitas, R., and Germida, J. J. 2020. Bacterial microbiome associated with the rhizosphere and root interior of crops in Saskatchewan, Canada. Can. J. Microbiol. 66:71-85.

Droby, S., and Wisniewski, M. 2018. The fruit microbiome: A new frontier for postharvest biocontrol and postharvest biology. Postharvest Biol. Technol. 140:107-112.

Edwards, J., Johnson, C., Santos-Medellín, C., Lurie, E., Kumar Podishetty, N., Bhatnagar, S., Eisen, J. A., and Sundaresan, V. 2015. Structure, variation, and assembly of the root-associated microbiomes of rice. Proc. Natl. Acad. Sci. U.S.A. 112:E911-E920.

Eyre, A. W., Wang, M., Oh, Y., and Dean, R. A. 2019. Identification and characterization of the core rice seed microbiome. Phytobiomes J. 3: 148-157.

Fan, K., Weisenhorn, P., Gilbert, J. A., Shi, Y., Bai, Y., and Chu, H. 2018. Soil $\mathrm{pH}$ correlates with the co-occurrence and assemblage process of diazotrophic communities in rhizosphere and bulk soils of wheat fields. Soil Biol. Biochem. 121:185-192.

Floc'h, J.-B., Hamel, C., Harker, K. N., and St-Arnaud, M. 2020. Fungal communities of the canola rhizosphere: Keystone species and substantial between-year variation of the rhizosphere microbiome. Microb. Ecol. 80: 762-777.

Foster, A., Vera, C. L., Malhi, S. S., and Clarke, F. R. 2014. Forage yield of simple and complex grass-legume mixtures under two management strategies. Can. J. Plant Sci. 94:41-50.

Fox, J., Weisberg, S., Price, B., Adler, D., Bates, D., Baud-Bovy, G., Bolker, B., Ellison, S., Firth, D., Friendly, M., Gorjanc, G., Graves, S., Heiberger, R., Krivitsky, P., Laboissiere, R., Maechler, M., Monette, G., Murdoch, D., Nilsson, H., Ogle, D., Ripley, B., Venables, W., Walker, S., Winsemius, D., Zeileis, A., and R-Core. 2020. car: Companion to Applied Regression. https:// cran.r-project.org/web/packages/car/index.html

Gdanetz, K., and Trail, F. 2017. The wheat microbiome under four management strategies, and potential for endophytes in disease protection. Phytobiomes J. 1:158-168.

Ge, J. C., Kim, H. Y., Yoon, S. K., and Choi, N. J. 2018. Reducing volatile organic compound emissions from diesel engines using canola oil biodiesel fuel and blends. Fuel 218:266-274.

Good, A. C., McKinnon, J. J., Penner, G. B., McAllister, T. A., and Mutsvangwa, T. 2017. Evaluation of canola meal versus soybean meal as a protein supplement on performance and carcass characteristics of growing and finishing beef cattle. J. Anim. Sci. 95:125-126

Gopal, M., and Gupta, A. 2016. Microbiome selection could spur nextgeneration plant breeding strategies. Front. Microbiol. 7:1971.

Government of Sasktatchewan. 2019. Crop Planning Guide 2019 - Complete Version. https://publications.saskatchewan.ca/\#/products/92833

Haron, M. H., Tyler, H. L., Chandra, S., Moraes, R. M., Jackson, C. R., Pugh, N. D., and Pasco, D. S. 2019. Plant microbiome-dependent immune enhancing action of Echinacea purpurea is enhanced by soil organic matter content. Sci. Rep. 9:136.

Hartman, W. H., Richardson, C. J., Vilgalys, R., and Bruland, G. L. 2008. Environmental and anthropogenic controls over bacterial communities in wetland soils. Proc. Natl. Acad. Sci. U.S.A. 105:17842-17847.

Hassani, M. A., Durán, P., and Hacquard, S. 2018. Microbial interactions within the plant holobiont. Microbiome 6:58.
Hothorn, T., Bretz, F., Westfall, P., Heiberger, R. M., Schuetzenmeister, A., and Scheibe, S. 2020. multcomp: Simultaneous Inference in General Parametric Models. https://cran.r-project.org/web/packages/multcomp/index.html

Jack, A. L. H., and Nelson, E. B. 2018. A seed-recruited microbiome protects developing seedlings from disease by altering homing responses of Pythium aphanidermatum zoospores. Plant Soil 422:209-222.

Khalaf, E. M., and Raizada, M. N. 2018. Bacterial seed endophytes of domesticated cucurbits antagonize fungal and oomycete pathogens including powdery mildew. Front. Microbiol. 9:42.

Kim, M.-S., Bae, J.-W., and Park, E.-J. 2018. Geographic and host-associated variations in bacterial communities on the floret surfaces of field-grown broccoli. Appl. Environ. Microbiol. 84:e02837-17.

Klaedtke, S., Jacques, M.-A., Raggi, L., Préveaux, A., Bonneau, S., Negri, V., Chable, V., and Barret, M. 2016. Terroir is a key driver of seed-associated microbial assemblages. Environ. Microbiol. 18:1792-1804.

Kumar, D., Maurya, N., Bharati, Y. K., Kumar, A., Kumar, K., Srivastava, K., Chang, G., Kushwaha, C., Singh, S. K., Mishra, R. K., and Kumar, A. 2014. Alternaria blight of oilseed Brassicas: A comprehensive review. Afr. J. Microbiol. Res. 8:2816-2829.

Kuźniar, A., Włodarczyk, K., Grządziel, J., Goraj, W., Gałązka, A., and Wolińska, A. 2020. Culture-independent analysis of an endophytic core microbiome in two species of wheat: Triticum aestivum L. (cv. 'Hondia') and the first report of microbiota in Triticum spelta L. (cv. 'Rokosz'). Syst. Appl. Microbiol. 43:126025.

Lauber, C. L., Hamady, M., Knight, R., and Fierer, N. 2009. Pyrosequencingbased assessment of soil $\mathrm{pH}$ as a predictor of soil bacterial community structure at the continental scale. Appl. Environ. Microbiol. 75:5111-5120.

Lay, C.-Y., Bell, T. H., Hamel, C., Harker, K. N., Mohr, R., Greer, C. W., Yergeau, E., and St-Arnaud, M. 2018. Canola root-associated microbiomes in the Canadian Prairies. Front. Microbiol. 9:1188.

Leff, J. W., Lynch, R. C., Kane, N. C., and Fierer, N. 2017. Plant domestication and the assembly of bacterial and fungal communities associated with strains of the common sunflower, Helianthus annuus. New Phytol. 214:412-423.

Lemanceau, P., Barret, M., Mazurier, S., Mondy, S., Pivato, B., Fort, T., and Vacher, C. 2017. Plant communication with associated microbiota in the spermosphere, rhizosphere and phyllosphere. Adv. Bot. Res. 82:101-133.

Links, M. G., Demeke, T., Gräfenhan, T., Hill, J. E., Hemmingsen, S. M., and Dumonceaux, T. J. 2014. Simultaneous profiling of seed-associated bacteria and fungi reveals antagonistic interactions between microorganisms within a shared epiphytic microbiome on Triticum and Brassica seeds. New Phytol. 202:542-553.

Liu, F., Hewezi, T., Lebeis, S. L., Pantalone, V., Grewal, P. S., and Staton, M. E. 2019. Soil indigenous microbiome and plant genotypes cooperatively modify soybean rhizosphere microbiome assembly. BMC Microbiol. 19:201.

Liu, S., Snowdon, R., and Chalhoub, B., eds. 2018. The Brassica napus Genome. Compendium of Plant Genomes. Springer, Cham, Switzerland.

Lloyd, D. A., Ritz, K., Paterson, E., and Kirk, G. J. D. 2016. Effects of soil type and composition of rhizodeposits on rhizosphere priming phenomena. Soil Biol. Biochem. 103:512-521.

Mandal, S., Van Treuren, W., White, R. A., Eggesbø, M., Knight, R., and Peddada, S. D. 2015. Analysis of composition of microbiomes: A novel method for studying microbial composition. Microb. Ecol. Health Dis. 26:27663.

Martin, M. 2011. Cutadapt removes adapter sequences from high-throughput sequencing reads. EMBnet. J. 17:10-12.

Martins, G., Lauga, B., Miot-Sertier, C., Mercier, A., Lonvaud, A., Soulas, M. L., Soulas, G., and Masneuf-Pomarède, I. 2013. Characterization of epiphytic bacterial communities from grapes, leaves, bark and soil of grapevine plants grown, and their relations. PLoS One 8:e73013.

Mavrodi, D. V., Mavrodi, O. V., Elbourne, L. D. H., Tetu, S., Bonsall, R. F., Parejko, J., Yang, M., Paulsen, I. T., Weller, D. M., and Thomashow, L. S. 2018. Long-term irrigation affects the dynamics and activity of the wheat rhizosphere microbiome. Front. Plant Sci. 9:345.

McMurdie, P. J., and Holmes, S. 2013. phyloseq: An R package for reproducible interactive analysis and graphics of microbiome census data. PLoS One 8:e61217.

Mina, D., Pereira, J. A., Lino-Neto, T., and Baptista, P. 2020. Impact of plant genotype and plant habitat in shaping bacterial pathobiome: A comparative study in olive tree. Sci. Rep. 10:3475.

Monreal, C. M., Zhang, J., Koziel, S., Vidmar, J., González, M., Matus, F., Baxi, S., Wu, S., DeRosa, M., and Etcheverria, P. 2018. Bacterial community structure associated with the addition of nitrogen and the dynamics of soluble carbon in the rhizosphere of canola (Brassica napus) grown in a Podzol. Rhizosphere 5:16-25. 
Moreira, Z. P. M., Helgason, B. L., and Germida, J. J. 2021 Crop, genotype, and field environmental conditions shape bacterial and fungal seed epiphytic microbiomes. Can. J. Microbiol. 67:161-173.

Mori, H., Maruyama, F., Kato, H., Toyoda, A., Dozono, A., Ohtsubo, Y., Nagata, Y., Fujiyama, A., Tsuda, M., and Kurokawa, K. 2014. Design and experimental application of a novel non-degenerate universal primer set that amplifies prokaryotic $16 \mathrm{~S}$ rRNA genes with a low possibility to amplify eukaryotic rRNA genes. DNA Res. 21:217-227.

Nelson, E. B. 2018. The seed microbiome: Origins, interactions, and impacts. Plant Soil 422:7-34.

Nicolaisen, M., Justesen, A. F., Knorr, K., Wang, J., and Pinnschmidt, H. O. 2014. Fungal communities in wheat grain show significant co-existence patterns among species. Fungal Ecol. 11:145-153.

Oksanen, J., Blanchet, F. G., Friendly, M., Kindt, R., Legendre, P., McGlinn, D., Minchin, P. R., O’Hara, R. B., Simpson, G. L., Solymos, P., Stevens, M. H. H., Szoecs, E., and Wagner, H. 2019. vegan: Community Ecology Package. https://cran.r-project.org/web/packages/vegan/index.html

Orozco-Mosqueda, M. del C., Rocha-Granados, M. del C., Glick, B. R., and Santoyo, G. 2018. Microbiome engineering to improve biocontrol and plant growth-promoting mechanisms. Microbiol. Res. 208:25-31.

Ottesen, A., Skaltsas, D., White, J. R., Gorham, S., Ramachandran, P., Brown, E., Newell, M., and Walsh, C. 2016. Using next generation sequencing to describe epiphytic microbiota associated with organic and conventionally managed apples. Int. J. Environ. Agric. Res. 2:36-42.

Paul, P. A., El-Allaf, S. M., Lipps, P. E., and Madden, L. V. 2004. Rain splash dispersal of Gibberella zeae within wheat canopies in Ohio. Phytopathology 94:1342-1349.

Quast, C., Pruesse, E., Yilmaz, P., Gerken, J., Schweer, T., Yarza, P., Peplies, J., and Glöckner, F. O. 2013. The SILVA ribosomal RNA gene database project: Improved data processing and web-based tools. Nucleic Acids Res. 41: D590-D596.

Raj, G., Shadab, M., Deka, S., Das, M., Baruah, J., Bharali, R., and Talukdar, N. C. 2019. Seed interior microbiome of rice genotypes indigenous to three agroecosystems of Indo-Burma biodiversity hotspot. BMC Genomics 20:924.

Rastogi, G., Tech, J. J., Coaker, G. L., and Leveau, J. H. J. 2010. A PCR-based toolbox for the culture-independent quantification of total bacterial abundances in plant environments. J. Microbiol. Methods 83:127-132.

Rezki, S., Campion, C., Simoneau, P., Jacques, M. A., Shade, A., and Barret, M. 2018. Assembly of seed-associated microbial communities within and across successive plant generations. Plant Soil 422:67-79.

Ricks, K. D., and Koide, R. T. 2019. The role of inoculum dispersal and plant species identity in the assembly of leaf endophytic fungal communities. PLoS One 14:e0219832.

Rochefort, A., Briand, M., Marais, C., Wagner, M.-H., Laperche, A., Vallée, P., Barret, M., and Sarniguet, A. 2019. Influence of environment and host plant genotype on the structure and diversity of the Brassica napus seed microbiota. Phytobiomes J. 3:326-336.

Ruiza, D., Agaras, B., de Werrab, P., Wall, L. G., and Valverde, C. 2011. Characterization and screening of plant probiotic traits of bacteria isolated from rice seeds cultivated in Argentina. J. Microbiol. 49: 902-912.

Rybakova, D., Mancinelli, R., Wikström, M., Birch-Jensen, A.-S., Postma, J., Ehlers, R.-U., Goertz, S., and Berg, G. 2017. The structure of the Brassica napus seed microbiome is cultivar-dependent and affects the interactions of symbionts and pathogens. Microbiome 5:104.

Schiessl, S., Huettel, B., Kuehn, D., Reinhardt, R., and Snowdon, R. J. 2017. Targeted deep sequencing of flowering regulators in Brassica napus reveals extensive copy number variation. Sci. Data 4:170013.

Sessitsch, A., and Mitter, B. 2015. 21st Century agriculture: Integration of plant microbiomes for improved crop production and food security. Microb. Biotechnol. 8:32-33.
Shade, A., Jacques, M. A., and Barret, M. 2017. Ecological patterns of seed microbiome diversity, transmission, and assembly. Curr. Opin. Microbiol. 37:15-22.

Shinwari, Z. K., Tanveer, F., and Iqrar, I. 2019. Role of microbes in plant health, disease management, and abiotic stress management. Pages 231-250 in: Microbiome in Plant Health and Disease. V. Kumar, R. Prasad, M. Kumar, and D. Choudhary, eds. Springer, Singapore.

Simonin, M., Dasilva, C., Terzi, V., Ngonkeu, E. L. M., Diouf, D., Kane, A., Béna, G., and Moulin, L. 2020. Influence of plant genotype and soil on the wheat rhizosphere microbiome: Evidences for a core microbiome across eight African and European soils. FEMS Microbiol. Ecol. 96:fiaa067.

Singh, B. K., and Trivedi, P. 2017. Microbiome and the future for food and nutrient security. Microb. Biotechnol. 10:50-53.

Singh, D., and Mathur, S. B., eds. 2004. Histopathology of Seed-Borne Infections. CRC Press, Boca Raton, FL, U.S.A.

Statistics Canada. 2020. Estimated areas, yield, production, average farm price and total farm value of principal field crops, in metric and imperial units. https://www150.statcan.gc.ca/t1/tbl1/en/tv.action?pid=3210035901

Tan, W., Wang, J., Bai, W., Qi, J., and Chen, W. 2020. Soil bacterial diversity correlates with precipitation and soil $\mathrm{pH}$ in long-term maize cropping systems. Sci. Rep. 10:6012.

Taye, Z. M., Helgason, B. L., Bell, J. K., Norris, C. E., Vail, S., Robinson, S. J., Parkin, I. A. P., Arcand, M., Mamet, S., Links, M. G., Dowhy, T., Siciliano, S., and Lamb, E. G. 2020. Core and differentially abundant bacterial taxa in the rhizosphere of field grown Brassica napus genotypes: Implications for canola breeding. Front. Microbiol. 10:3007.

Toju, H., Peay, K. G., Yamamichi, M., Narisawa, K., Hiruma, K., Naito, K., Onoda, Y., Yoshida, K., Schlaeppi, K., Bai, Y., Sugiura, R., Ichihashi, Y., Minamisawa, K., and Kiers, E. T. 2018. Core microbiomes for sustainable agroecosystems. Nat. Plants 4:247-257.

Toju, H., Tanabe, A. S., Yamamoto, S., and Sato, H. 2012. High-coverage ITS primers for the DNA-based identification of ascomycetes and basidiomycetes in environmental samples. PLoS One 7:e40863.

Tosi, M., Kovalski Mitter, E., Gaiero, J., and Dunfield, K. E. 2020. It takes three to tango: The importance of microbes, host plant and soil management to elucidate manipulation strategies for the plant microbiome. Can. J. Microbiol. 66:413-433.

Truyens, S., Beckers, B., Thijs, S., Weyens, N., Cuypers, A., and Vangronsveld, J. 2016. Cadmium-induced and trans-generational changes in the cultivable and total seed endophytic community of Arabidopsis thaliana. Plant Biol. 18:376-381.

Walitang, D. I., Kim, C. G., Jeon, S., Kang, Y., and Sa, T. 2018. Conservation and transmission of seed bacterial endophytes across generations following crossbreeding and repeated inbreeding of rice at different geographic locations. MicrobiologyOpen 8:e0662.

Walitang, D. I., Kim, K., Madhaiyan, M., Kim, Y. K., Kang, Y., and Sa, T. 2017. Characterizing endophytic competence and plant growth promotion of bacterial endophytes inhabiting the seed endosphere of Rice. BMC Microbiol. 17:209.

Walters, W. A., Jin, Z., Youngblut, N., Wallace, J. G., Sutter, J., Zhang, W., González-Peña, A., Peiffer, J., Koren, O., Shi, Q., Knight, R., del Rio, T. G., Tringe, S. G., Buckler, E. S., Dangl, J. L., and Ley, R. E. 2018. Largescale replicated field study of maize rhizosphere identifies heritable microbes. Proc. Natl. Acad. Sci. U.S.A. 115:7368-7373.

Wassermann, B., Adam, E., Cernava, T., and Berg, G. 2019. Understanding the indigenous seed microbiota to design bacterial seed treatments. Pages 83-99 in: Seed Endophytes. S. Verma and J. White, Jr., eds. Springer, Cham, Switzerland.

Zhang, B., Zhang, J., Liu, Y., Shi, P., and Wei, G. 2018. Co-occurrence patterns of soybean rhizosphere microbiome at a continental scale. Soil Biol. Biochem. 118:178-186.

Zhong, Y., Yang, Y., Liu, P., Xu, R., Rensing, C., Fu, X., and Liao, H. 2019. Genotype and rhizobium inoculation modulate the assembly of soybean rhizobacterial communities. Plant Cell Environ. 42:2028-2044.

Zilber-Rosenberg, I., and Rosenberg, E. 2008. Role of microorganisms in the evolution of animals and plants: The hologenome theory of evolution. FEMS Microbiol. Rev. 32:723-735. 